\title{
Mineralogical Properties of Cracking Clay Soils along Toposequence At Northern Upper Clay Plains of Nuba Mountains South Kordofan, Sudan
}

\author{
Omima Omer A. Showgi ${ }^{1}$, El-Abbas Doka M. Ali ${ }^{2}$, Hashim Ali \\ Dawoud $^{3}$ and Mahgoub Suliman Mohamedain ${ }^{*}$
}

\author{
${ }^{1}$ Properties and Genesis of Soils, College of Science and Technology, Department of Botany. \\ Shendi University, Shendi, Nile State \\ ${ }^{2}$ Land Evaluation and Remote Sensing.College of Agricultural Studies, Sudan University of \\ Science and Technology, Shambat, Sudan \\ ${ }^{3}$ Soil Pedology and land Use Planning, Department of Horticulture Science, College of \\ Agriculture, Al Azhari University, Khartoum North, Sudan \\ ${ }^{4}$ Remote Sensing for Forest Management, College of Forestry and Range Science, Sudan \\ University of Science and Technology, Sudan \\ *Corresponding author
}

\section{A B S T R A C T}

\begin{tabular}{l} 
K e y w o r d s \\
Nuba Mountains; \\
Cracking Clay \\
soils; \\
Upper clay \\
plains, \\
Clay Mineralogy. \\
\hline Article Info \\
\hline Accepted: \\
28 June 2016 \\
Available Online: \\
10 August 2016 \\
\end{tabular}

This research study was carried to identify the mineralogical properties of the cracking clay soils (Vertisols) at the upper clay plains located at the north eastern parts of Nuba Mountains, Sudan. Soil samples were collected from profile pits along a toposequence in a transect stretching about $85 \mathrm{~km}$ from Samasim to Dalami. The area is an intermountain, slightly undulating clay plain surrounded by the Nuba mountains and hills. The majority of the soils identified belong to the dark cracking clays. The huge mantle of clay rests on the basement complex but the origin of this clay is somewhat controversial, it is either transported from another place and deposited were it is or formed in situ. According to previous studies, clay minerals particularly smectite are sensitive to pressure and temperature conditions and to variations in the chemical environment (sensitivity is expressed as crystallographic and mineralogical changes). Consequently, the study of clays can supply a great deal of information concerning the processes that occur in the evolution of the sequences of which they form a part such as weathering, hydrothermal alteration, digenesis, low grade metamorphism, etc. Furthermore, clay may reflect the history of the sediments better than any other component, because the characteristics of the clay minerals are to some extent subject to changes depending on the environment in which they are found. The $\mathrm{x}$ - ray diffraction (XRD) analysis was used to identify quantitatively and semi-quantitatively the proportion of each clay mineral with respect to other clay minerals present in the tested samples. The $\mathrm{X}$ - Ray diffraction analyses of samples in these profiles indicates that the dominant clay minerals is Smectite with percentages ranging between $84.6-49.5 \%$ followed by kaolinite $41.5-8.2 \%$, chlorite $6.5-1.6 \%$, illite $6.2-2.1 \%$ and Semctite $\backslash$ Chlorite 4.1 $1.3 \%$. The bulk mineral analysis indicate the present quartz minerals found in all profiles with percentages of 54.0, 48.0, 45.5, 32.8, 29.8, 35.4, 56.9, 61.6; mica is found in all 7 profiles except profile 10 with percentages of $46.0,50.4,41.8,32.1,70.1,58.8,41.6$; silliminite present in profiles $16,14,11$ with percentages of $1.6,35.1,1.5$; Kaolinite present only in profile 15 with percentage of 12.3; calcite is found only in profiles 13,10 with percentages of $0.1,7.7$ and magnetite exist in profiles 12 and 10 with percentages of 9.7, 30.6. In aggregates this mineralogical assemblages occurring in three areas suggest origins of parent materials derived from basic igneous Imetamorphic rocks that have under gone weathering and in situ formation of clay minerals that have imposed magnitude of variations in the Pedological features. 


\section{Introduction}

In the Sudan, Vertisols occur on large tract of land, totalling perhaps 50 million ha in area, is divided naturally into four separated areas: the central clay plain (Gezira), the eastern clay plain (Gadarif), the Nuba Mountains region and the southern clay plain (Abyei-Bahr Al Arab). Vertisol in the Nuba Mountains region occur on gently undulating plains and have better surface drained than in extremely flat landscape of the other three clay plains. Dark cracking clay soils "Vertisols" cover not only large areas of the low-lying plains but also they occur on undulating higher plains and in many intermountain valleys throughout the Nuba Mountains area. Some of these clays, notably those in eastern and southern lower clay plains, Khor Abu Habil, Wadi Al Ghalla and the clays of Bahr el Arab valley, can only be alluvial (Ahmed, 1996; Osman, 2006;). But some other clay, for instance, on undulating high plains in the Nuba Mountains uplands area indicate a nonalluvial origin.

The Nuba Mountains Vertisols are considered to be derived from the underlying bedrock (Pacheco and Dawoud, 1976). Therefore, it is expected that the parent materials at upper clay plains have undergone through a shorter pedogenetic processes compared to those on low alluvial plains. These non-alluvial clays are thought to be moved slowly down slope by combined process of wash and mass movement. Bases are thought to be washed from higher areas to accumulate on the plains where they help in the formation of the higher base status clays. These soils are plastic, sticky and have moderately high-tohigh cation exchange capacities and a high capacity to shrink and swell with changes in moisture (Garry, 1996). Because the lower horizons are subject to pressure when the soils swell, they are compact and very slowly permeable to water. They are usually neutral to slightly in reaction (Pacheco and Dawoud, 1976).

This research study attempts to identify the mineralogical properties of the Vertisols at upper clay plains in Nuba Mountains, which provide information on soil forming processes and development of the soil. Many research studies were carried to characterize the clay minerals of Vertisols at different parts the alluvial low clay plains of Sudan and elsewhere in the world (Dudal, 1988; Chizhikova, 2005; Balwant, 2002). The rainfed lands found less detailed research attention and particularly the upper clay plains at Nuba Mountains region that need more understanding of their formation and behaviour as related to their use and management. Since the Vertisols in Nuba Mountains region occur in topographic sequence of plains (upper, middle and lower plains); then the mineralogical characterization provided by this study will lay the bases for the subsequent research efforts to study these soils.

\section{The Study Area}

The study area is located in the Northern part of the Nuba Mountains in South Kordofan State. The sampling transect (110 $\mathrm{Km}$ ), starts from Habila scheme (Samasim height $774 \mathrm{~m}$ asl) in the south west and ending eastward at Dalami (height $628 \mathrm{~m}$ asl). It has tropical semi - arid (steppe) zone of summer rain. The rainfall is comparatively high as the survey area lies within isohyets $600-800 \mathrm{~mm}$ (Table 1). The rainy season starts from late June and extends to early October month. Maximum temperatures range between $31 \mathrm{C}^{\circ}$ and $40 \mathrm{C}^{\circ}$ with March to May as the hottest months and monthly minimum temperatures range between $17 \mathrm{C}^{\mathrm{O}}$ and $24 \mathrm{C}^{\mathrm{O}}$ with coldest months being from early December to the 
end February. In Habila, relative humidity is $70 \%$ in July - August and falls to $20-25 \%$ during winter (ELtom, 1972 and Dawoud, 1974).

\section{Materials and Methods}

Transect along the toposequence stretches in eastward direction from Habila scheme to Dalami. The area under study is situated between longitudes $32^{\circ} 40^{\prime \prime}$ and $29^{\circ} 35^{\prime \prime}$ East and latitudes $11^{\circ} 56^{\prime \prime}$ and $12^{\circ} 09^{\prime \prime}$ north. Eight samples were collected from eight sites shown in Table 3 and represented in Figure 2. Sub-scenes of Landsat TM Satellite image 2010 covering the study area were used for locating the sampling sites.

A pit of about $1 \times 2 \mathrm{~m}$ in length with $1.5 \mathrm{~m}$ depth was dug for sampling at each site. Notes on morphology, horizons sequence and soil classification were recorded following the standard procedures. Eight soil samples, one from each soil profile were selected for identification of clay mineralogy by x-ray diffraction. The analysis of clay minerals took place in two steps, via separation of the less than $2 \mu$ fraction and then $\mathrm{x}$ - ray diffraction technique. The $<2 \mu$ clay fraction was filtered through a ceramic filter using a suction pump. The filtrate was collected in dishes and kept in an oven at 50 $0 \mathrm{C}$ for subsequent analysis. From the wet clay fraction $(<2 \mu)$ oriented mounds were prepared on glass slides to obtain basal reflections of clay. The thus prepared glass slides were kept in desiccators for 24 hours to dry and then taken for air - dried measurements.

The $\mathrm{x}$ - ray diffraction (XRD) analysis was used to identify quantitatively and semiquantitatively the proportion of each clay mineral with respect to other clay minerals present in the tested samples. The concise summary of the application and interpretation of the XRD techniques that was provided by Tucker (1988) was followed and that the qualification of these minerals was made following Thorez (1972). The XRD analyses were performed using Simians D500x-ray diffractometer. The clay minerals were identified from their 0.01 repeated basal reflections that were obtained from the XRD patterns after air drying (normal), glycolation for 48 hours and after heating to $550 \mathrm{C}^{0}$ for four hours. The relative proportion of each mineral was estimated as provided by Thorez (1975). The total association of minerals was taken to be equal to100 per cent. The heights of peaks of the basal reflection 0.01 of the clay mineral were measured above the background and are considered as the proportion of that mineral in the sample. The most basic application of $\mathrm{XRD}$ to sediments is in the analysis of the Bulk minerals, to obtain satisfactory results, the original grain size must be reduced to a mean particles diameter of $5-10$ um with performable a limited size range. Having ground representative sample to the appropriate grain size, the next stage is to present the sample to the XRD beam.

\section{Results and Discussion}

$\mathrm{X}$ - Ray diffraction analyses of samples in these profiles indicates that the dominant clay minerals is Smectite with percentages ranging between $84.6-49.5 \%$ followed by kaolinite 41.5 - 8.2\%, chlorite $6.5-1.6 \%$, illite $6.2-2.1 \%$ and Semctitel Chlorite 4.1 1.3\% (Table 4 and Figures 3, 5, 7, 9, 11, 13, 15 and 17). The bulk mineral analysis indicate the present quartz minerals found in all profiles with percentages of 54.0, 48.0, $45.5,32.8,29.8,35.4,56.9,61.6$; mica is found in all 7 profiles except profile 10 with percentages of $46.0,50.4,41.8,32.1,70.1$, $58.8,41.6$; silliminite present in profiles 16 , 14, 11 with percentages of $1.6,35.1,1.5$; Kaolinite present only in profile 15 with 
percentage of 12.3 ; calcite is found only in profiles 13,10 with percentages of $0.1,7.7$ and magnetite exist in profiles 12 and 10 with percentages of $9.7,30.6$ (Table 5 and Figures 4, 6, 8, 10, 12, 14, 16 and 18).

Table.1 Rainfall at the Study Area

\begin{tabular}{|c|c|c|c|c|c|}
\hline Season & Dilling & Habila & Season & Dilling & Habila \\
\hline $\mathbf{1 9 9 7}-\mathbf{1 9 9 8}$ & 564.5 & 460.5 & $\mathbf{2 0 0 2}-\mathbf{2 0 0 3}$ & 727.5 & 695 \\
\hline $\mathbf{1 9 9 8}-\mathbf{1 9 9 9}$ & 840 & 840 & $\mathbf{2 0 0 3}-\mathbf{2 0 0 4}$ & 526 & 566 \\
\hline $\mathbf{1 9 9 9}-\mathbf{2 0 0 0}$ & 735.5 & 488.6 & $\mathbf{2 0 0 4}-\mathbf{2 0 0 5}$ & 606.2 & 513.5 \\
\hline $\mathbf{2 0 0 0}-\mathbf{2 0 0 1}$ & 526.5 & 429 & $\mathbf{2 0 0 5}-\mathbf{2 0 0 6}$ & 519.5 & 734 \\
\hline $\mathbf{2 0 0 1}-\mathbf{2 0 0 2}$ & 648.2 & 498 & $\mathbf{2 0 0 6}-\mathbf{2 0 0 7}$ & 730 & 1143 \\
\hline
\end{tabular}

Table.2 Sample sites, location and elevation along the toposequence

\begin{tabular}{|c|c|c|c|c|}
\hline Area & Sample site & North & East & Elevation (m) \\
\hline \multirow{8}{*}{$\begin{array}{c}\text { Habila } \\
\text { (intermountain } \\
\text { upper clay plains) }\end{array}$} & HA017 & $11^{\circ} 53^{\prime} 06.00^{\prime \prime}$ & $29^{\circ} 35^{\prime} 47.00^{\prime \prime}$ & 774 \\
\hline & HA016 & $11^{\circ} 51^{\prime 2} 29.00^{\prime \prime}$ & $29^{\circ} 49^{\prime} 57.00^{\prime \prime}$ & 766 \\
\hline & HA015 & $11^{\circ} 51^{\prime} 58.00$ ' & $29^{\circ} 52^{\prime} 56.00^{\prime \prime}$ & 747 \\
\hline & HA014 & $11^{\circ} 3^{\prime} 54.00^{\prime \prime}$ & $29^{\circ} 56^{\prime} 54.00^{\prime \prime}$ & 734 \\
\hline & HA013 & $11^{\circ} 44^{\prime} 00.00^{\prime \prime}$ & $30^{\circ} 05^{\prime} 00.00^{\prime \prime}$ & 697 \\
\hline & HA012 & $11^{\circ} 45^{\prime} 01.00^{\prime}$ & $30^{\circ} 01^{\prime} 04.00^{\prime \prime}$ & 663 \\
\hline & HA011 & $11^{\circ} 45^{\prime} 54.00^{\prime \prime}$ & $30^{\circ} 11^{\prime} 57.00^{\prime \prime}$ & 647 \\
\hline & HA010 & $11^{\circ} 51^{\prime} 46.00^{\prime \prime}$ & $30^{\circ} 28^{\prime} 14.00^{\prime \prime}$ & 628 \\
\hline
\end{tabular}

Table.3 Clay Minerals Analysis of Study area Samples.

\begin{tabular}{|c|l|c|c|c|c|c|}
\hline Sites & $\begin{array}{l}\text { Profile } \\
\text { No }\end{array}$ & $\begin{array}{c}\text { Smectit } \\
\text { e \% }\end{array}$ & $\begin{array}{c}\text { Kaolinit } \\
\text { e \% }\end{array}$ & $\begin{array}{c}\text { Illit } \\
\text { e\% }\end{array}$ & $\begin{array}{c}\text { Chlori } \\
\text { te\% }\end{array}$ & $\begin{array}{c}\text { Smectite/ } \\
\text { Chlorite \% }\end{array}$ \\
\hline Samasim & HA017 & 66.3 & 27.3 & 2.5 & 2.3 & 1.60 \\
\hline \multirow{3}{*}{ Habila } & HA016 & 58.9 & 30.0 & 4.7 & 2.4 & 3.97 \\
\cline { 2 - 7 } & HA015 & 49.5 & 41.5 & 2.1 & 3.7 & 3.20 \\
\cline { 2 - 7 } Fayo & HA014 & 76.0 & 12.1 & 5.0 & 2.8 & 4,10 \\
\hline \multirow{3}{*}{ Dalami } & HA013 & 71.3 & 17.4 & 3.5 & 6.5 & 1.30 \\
\cline { 2 - 7 } & HA012 & 66.8 & 23.0 & 6.2 & 2.0 & 2.00 \\
\cline { 2 - 7 } & HA011 & 76.7 & 10.6 & 5.5 & 3.7 & 3.50 \\
\hline
\end{tabular}


Fig.1 Topographic Sequence at Northern Upper Clay Plains of

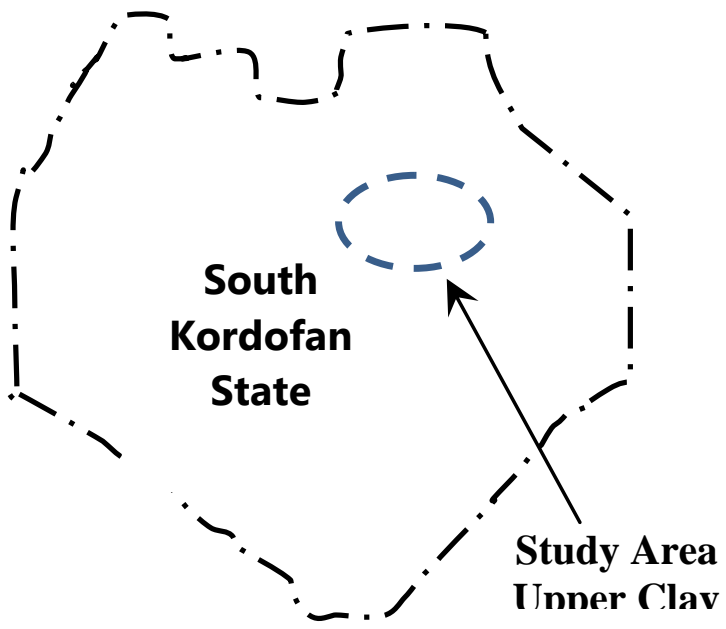

Fig.2 Landsat scene showing the Study area and the sampling sites starting from Habila on the west to Dalami on the east

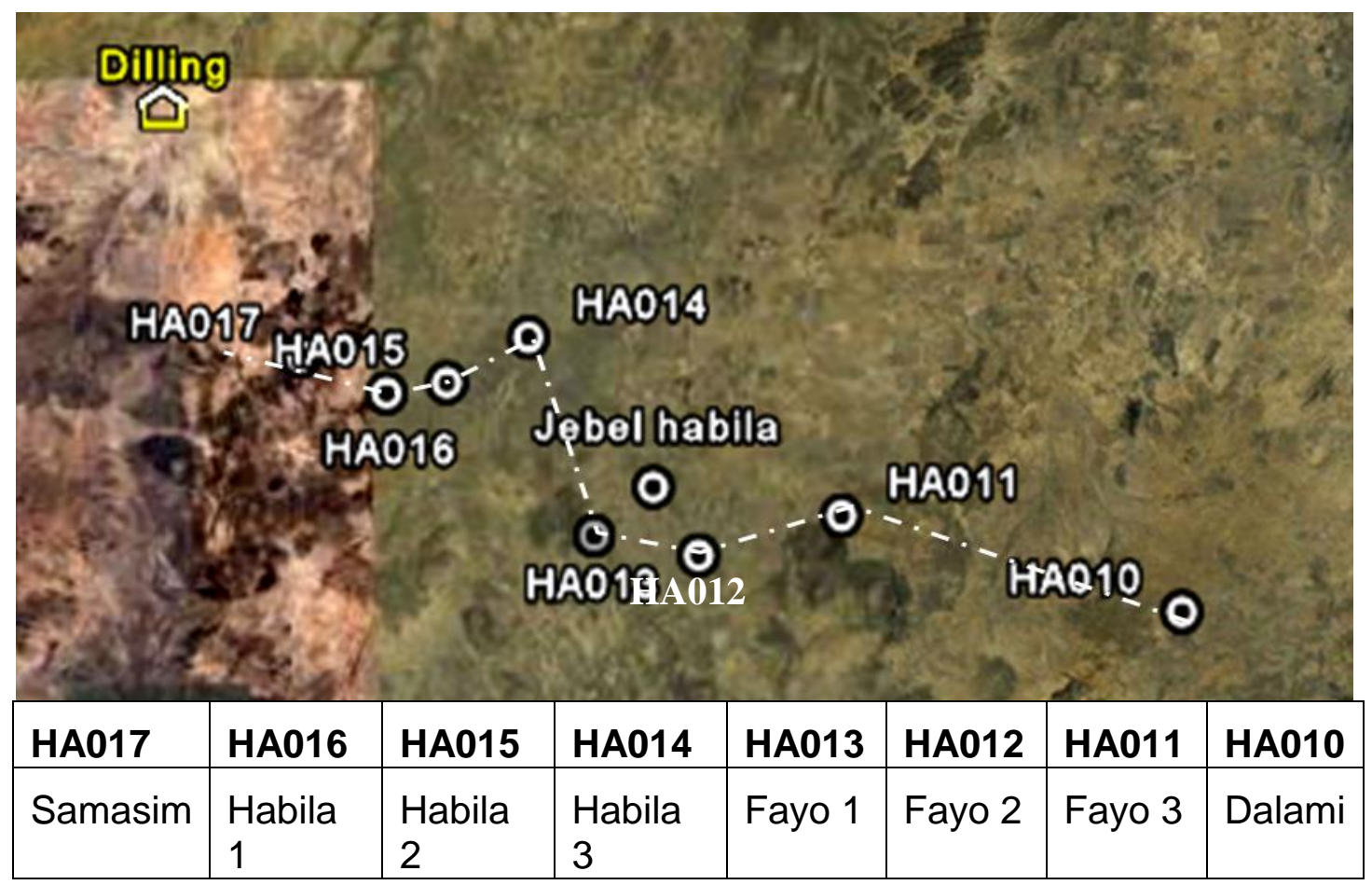


Table.4 Bulk Minerals Analyses of the Study Area Samples.

\begin{tabular}{|c|c|c|c|c|c|c|c|}
\hline \multirow{4}{*}{ Sites } & \multirow{4}{*}{$\begin{array}{c}\text { Sample } \\
\text { No }\end{array}$} & \multicolumn{6}{|c|}{ Detrital Mineral grains } \\
\hline & & \multicolumn{4}{|c|}{ Silicates } & \multirow{2}{*}{\multicolumn{2}{|c|}{$\begin{array}{c}\text { Non- } \\
\text { silicates }\end{array}$}} \\
\hline & & \multirow{2}{*}{\begin{tabular}{|c|} 
Sand +Silt \\
Magnetite \\
$\%$
\end{tabular}} & \multicolumn{3}{|c|}{ Clay } & & \\
\hline & & & $\begin{array}{c}\text { Calcite } \\
\%\end{array}$ & $\begin{array}{c}\text { Kaolinite } \\
\%\end{array}$ & $\begin{array}{c}\text { Mica } \\
\%\end{array}$ & $\begin{array}{c}\text { Sillimanite } \\
\%\end{array}$ & $\underset{\%}{\text { Quartz }}$ \\
\hline Samasim & HA017 & 54.0 & Traces & 46,0 & Traces & - & - \\
\hline \multirow{3}{*}{$\begin{array}{l}\text { Habila } \\
\text { area }\end{array}$} & HA016 & 48.0 & 1.6 & 50.4 & Traces & - & - \\
\hline & HA015 & 45.5 & - & 41.8 & 12.3 & - & traces \\
\hline & HA014 & 38.2 & 35.1 & 32.1 & Traces & - & - \\
\hline \multirow[t]{3}{*}{ Fayo area } & HA013 & 29.8 & - & 70.1 & Traces & 0.1 & - \\
\hline & HA012 & 35.4 & - & 54.8 & Traces & - & 9.7 \\
\hline & HA011 & 56.9 & 1.5 & 41.6 & - & - & - \\
\hline Dalami & HA010 & 61.1 & - & - & Traces & 7.7 & 30.6 \\
\hline
\end{tabular}

Fig.3 The XRD pattern of clay minerals of the soil sample from Samasim $(58-89 \mathrm{~cm})$.

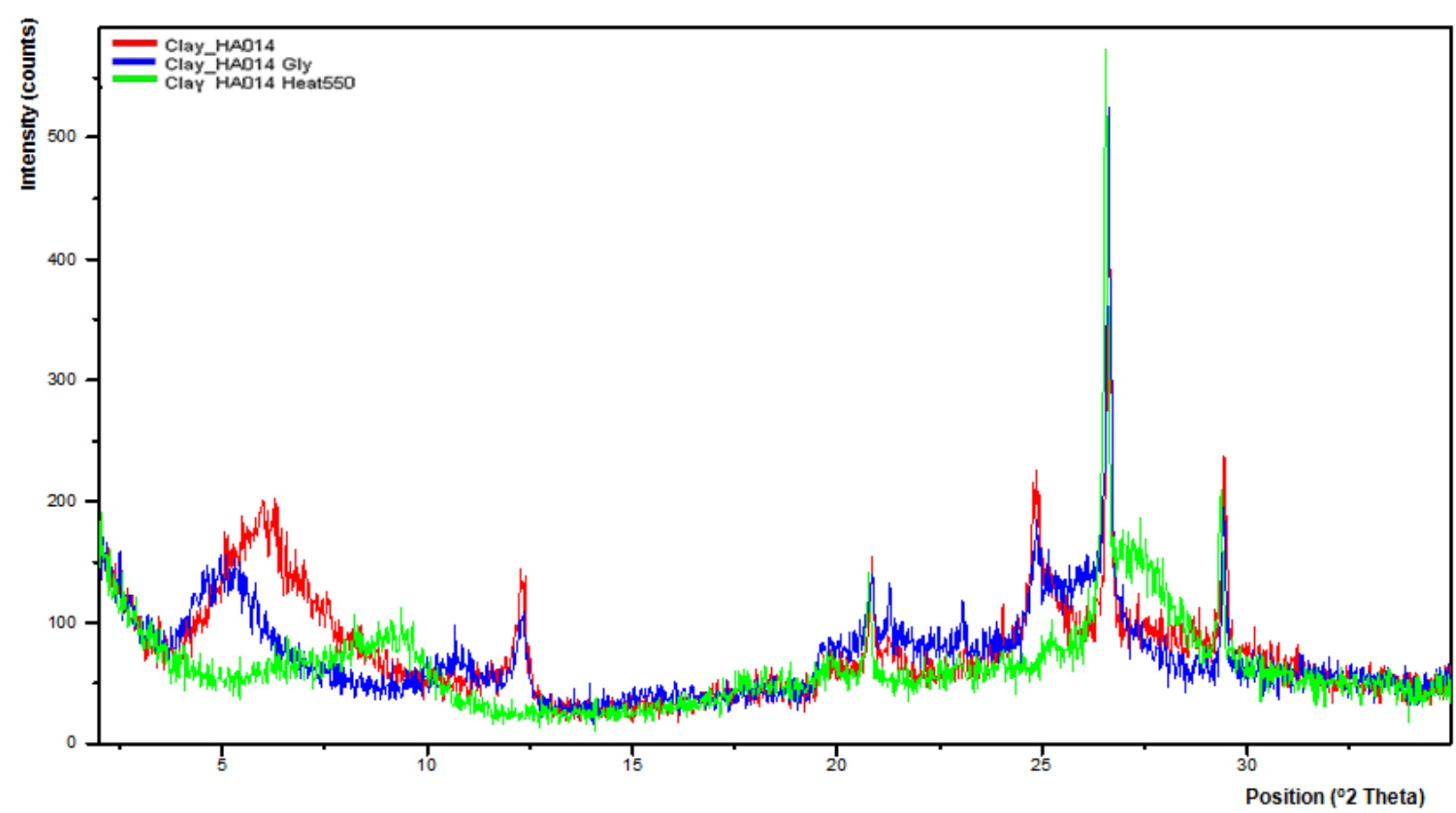


Fig.4 The X RD pattern of bulk minerals of the soil sample from Samasim $(58-89 \mathrm{~cm})$

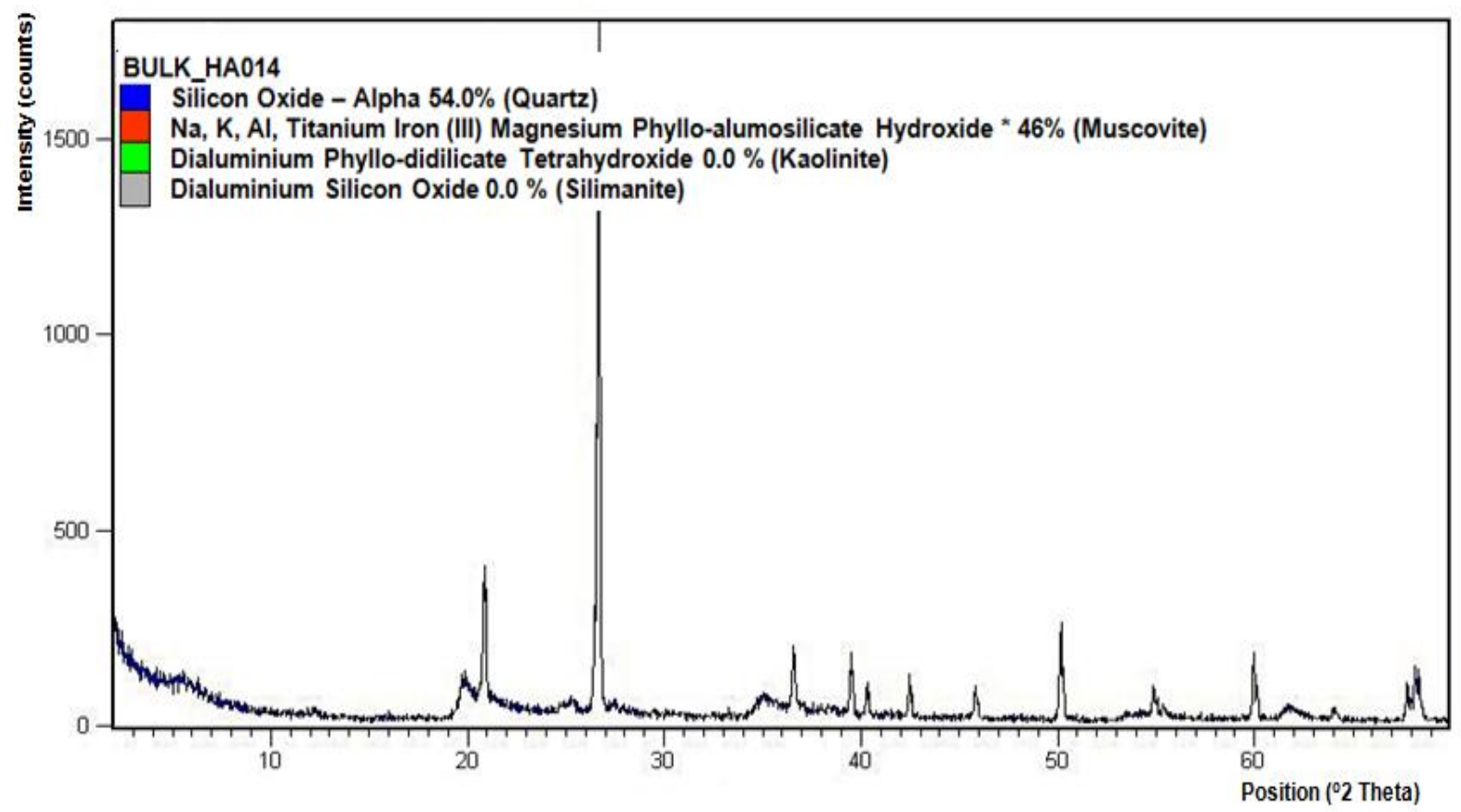

Fig.5 The XRD pattern of clay minerals of the soil sample from Habila1 $(63-99 \mathrm{~cm})$

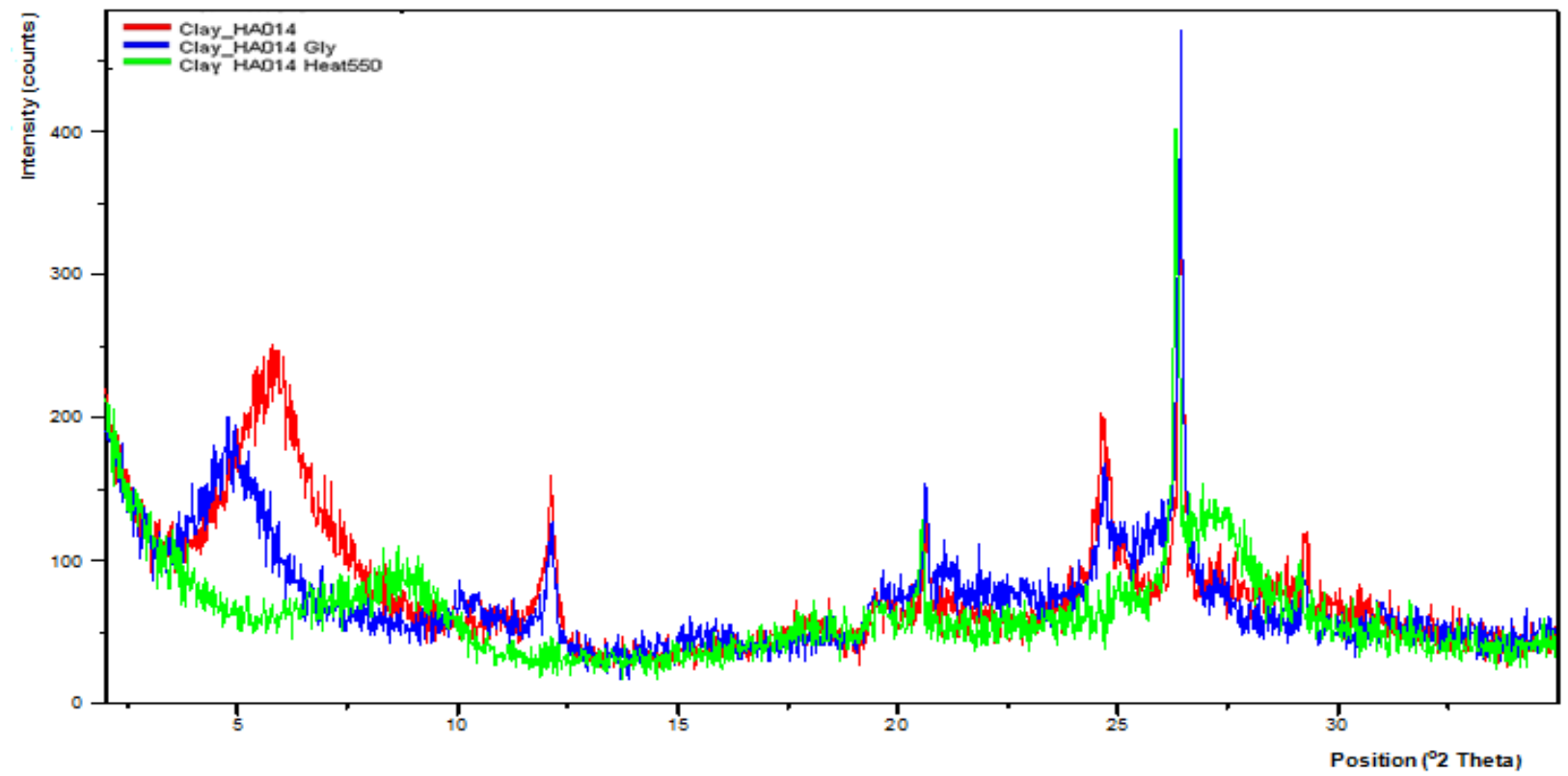


Fig.6 The XRD pattern of bulk minerals of the soil sample from Habila1 $(63-99 \mathrm{~cm})$

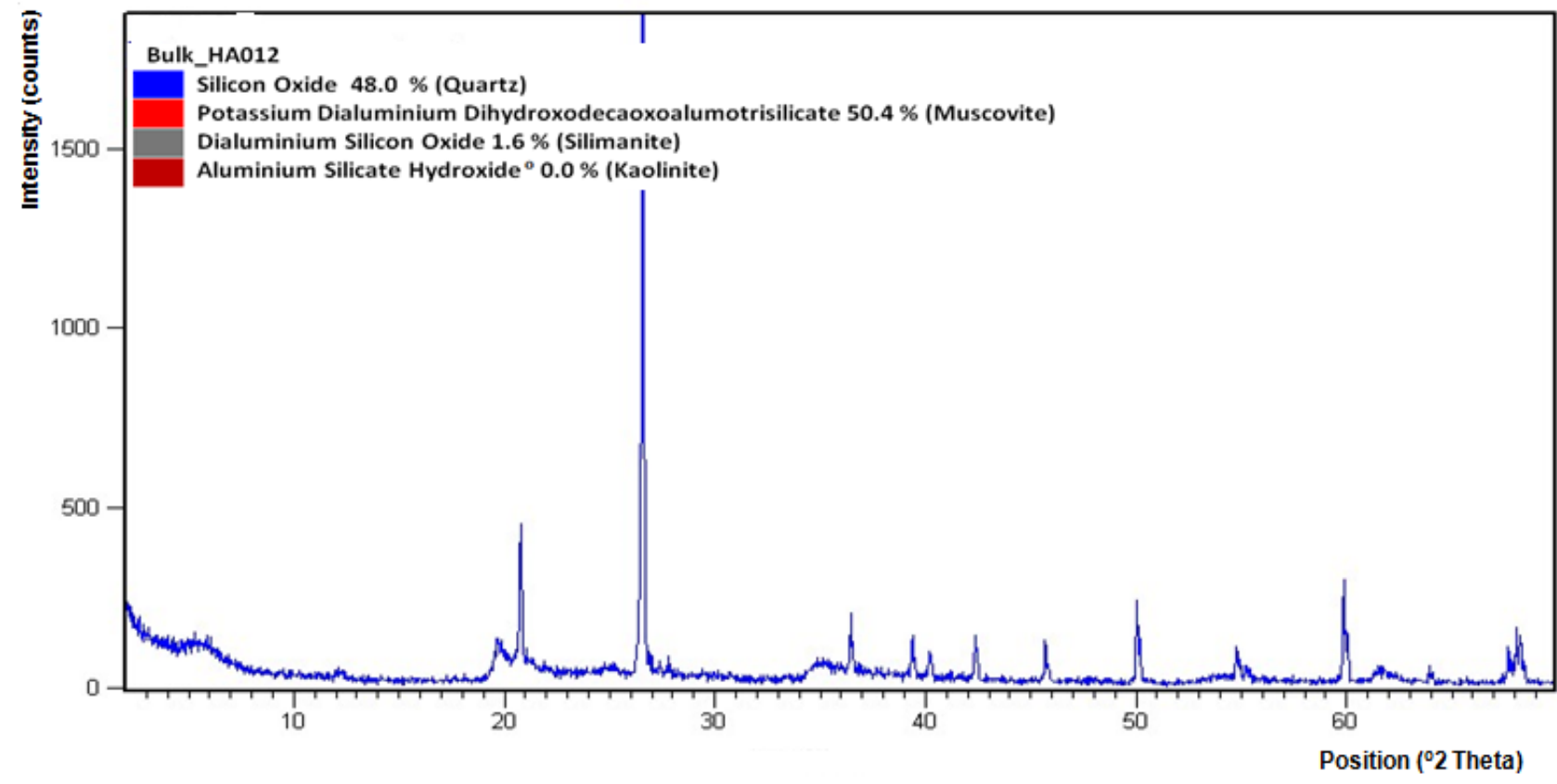

Fig.7 The X RD pattern of clay minerals of the soil sample from Habila $2(40-88 \mathrm{~cm})$.

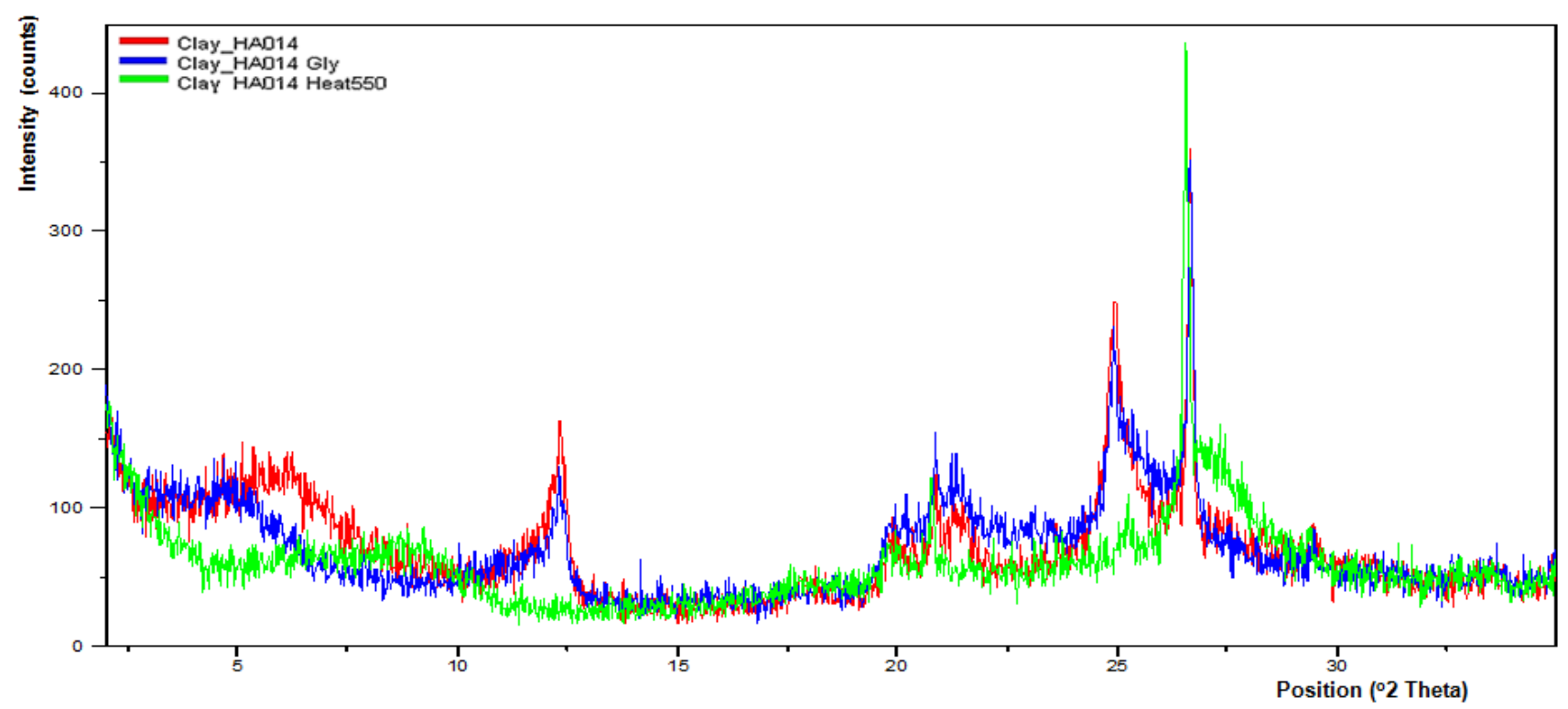


Fig.8 The XRD pattern of bulk minerals of the soil sample from Habila $2(40-88 \mathrm{~cm})$.

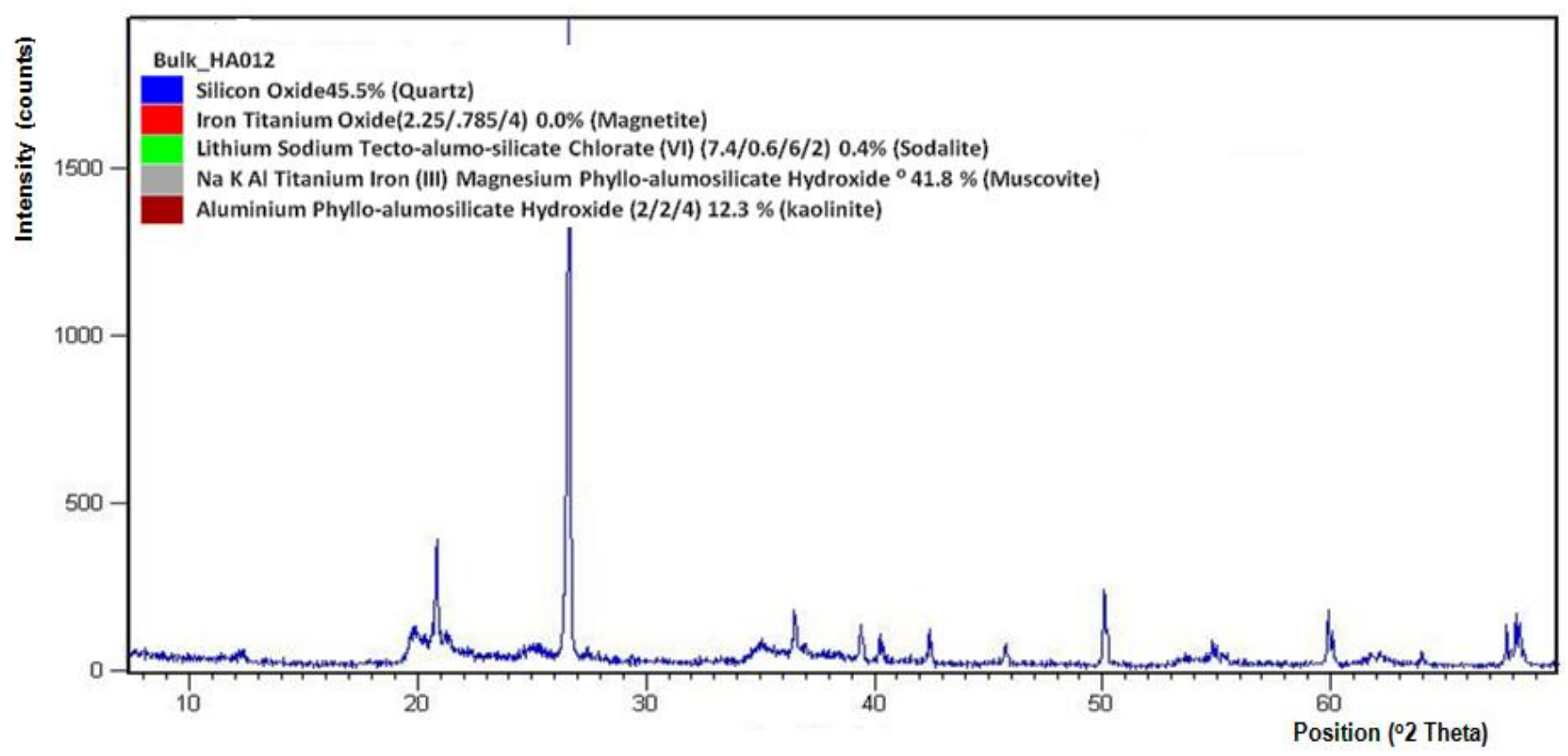

Fig.9 The X RD pattern of clay minerals of the soil sample from Habila $3(52-86 \mathrm{~cm})$

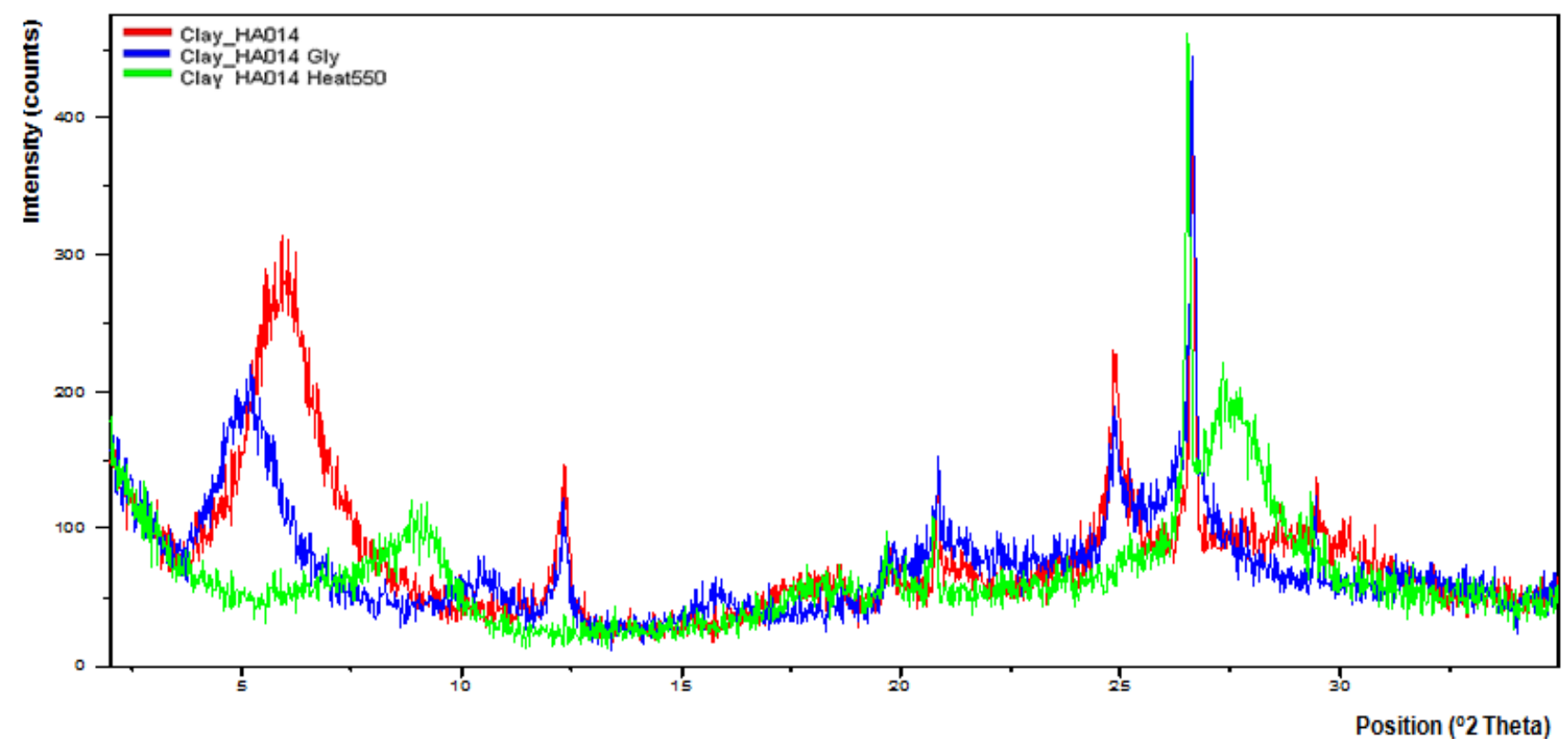


Fig.10 The X RD pattern of bulk minerals of the soil sample from Habila $3(52-96 \mathrm{~cm})$.

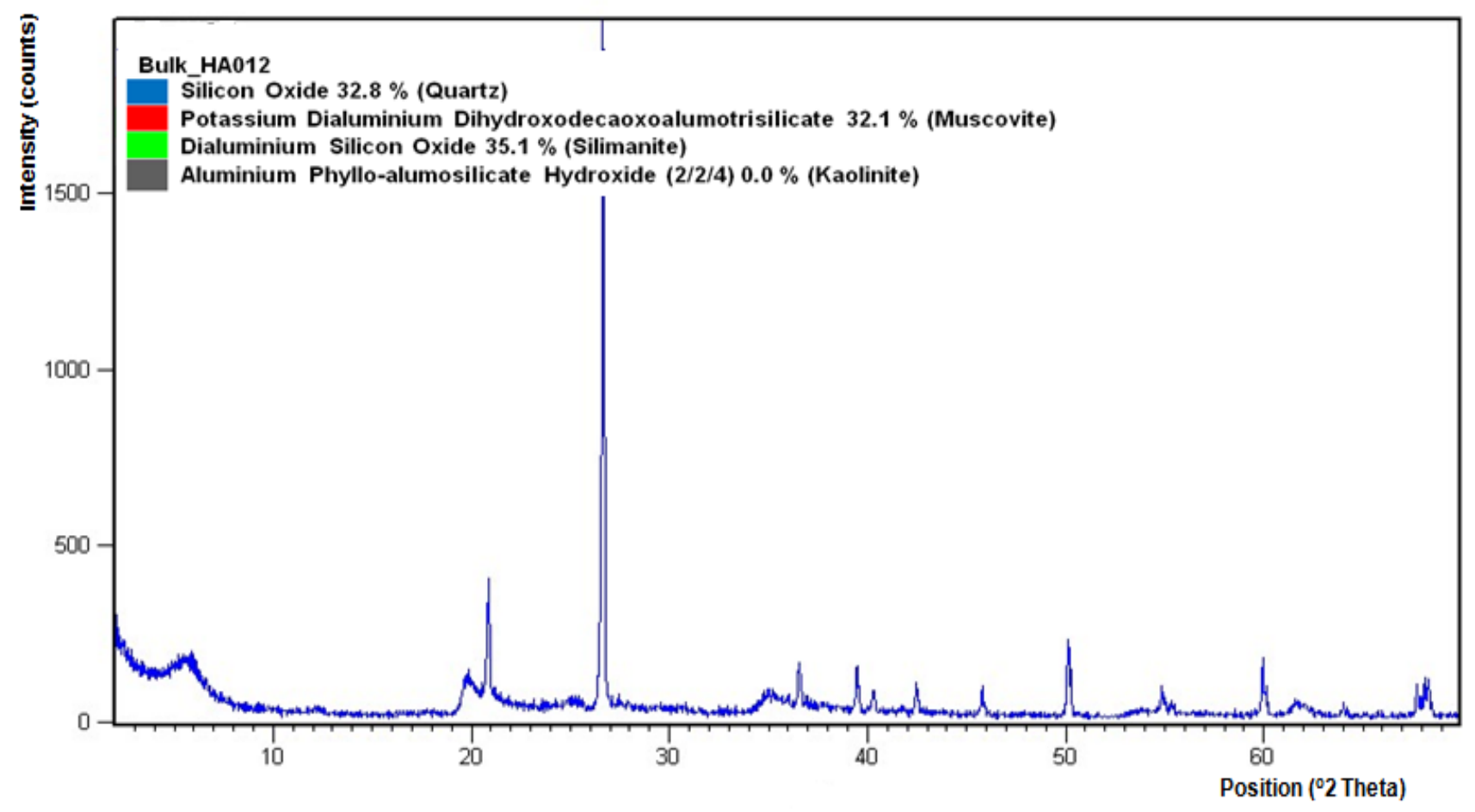

Fig.11 The X RD pattern of clay minerals of the soil sample from Fayo1 $(57-93 \mathrm{~cm})$.

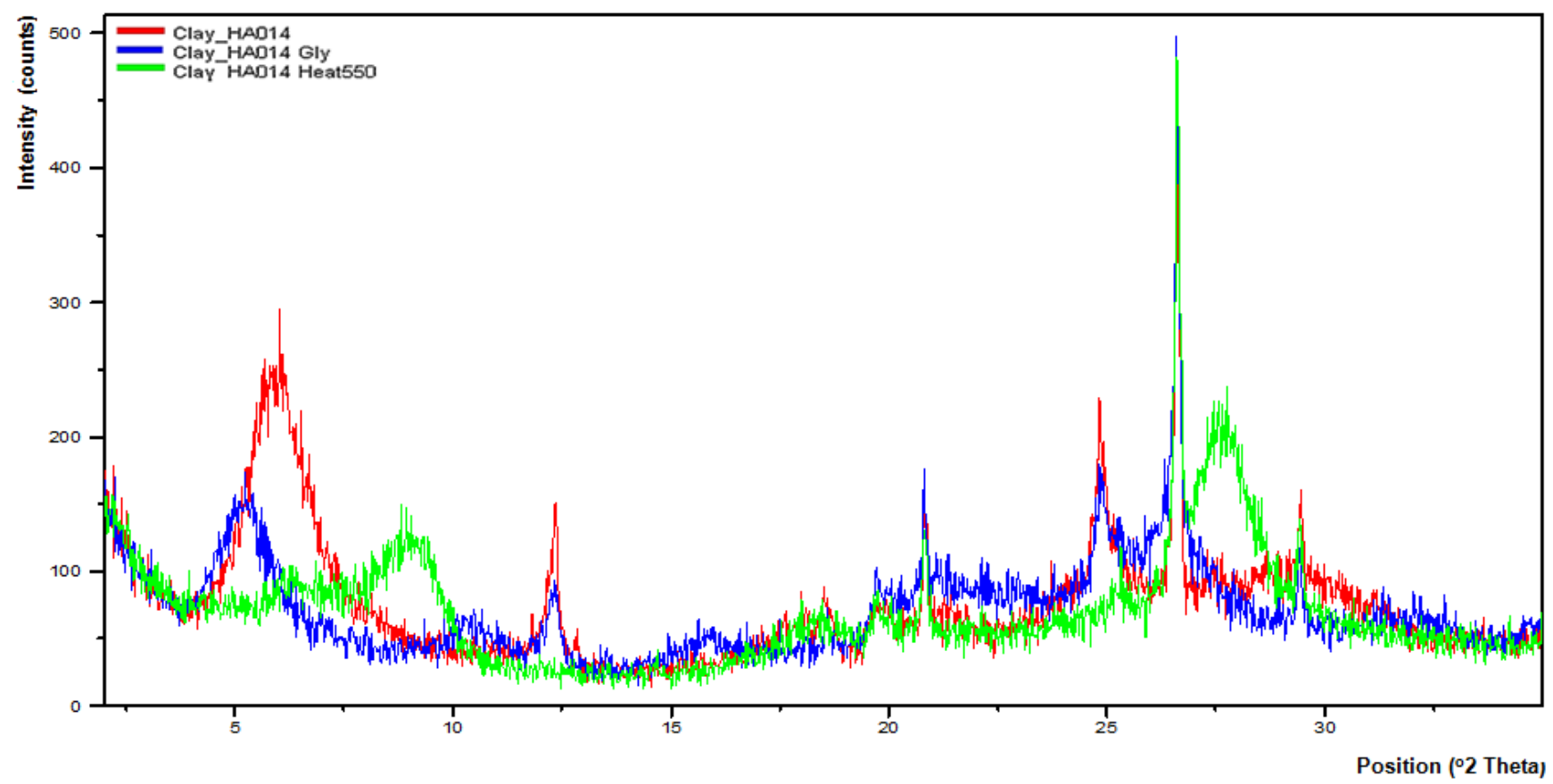


Fig.12 The X RD pattern of bulk minerals of the soil sample from Fayo1 $(57-93 \mathrm{~cm})$.

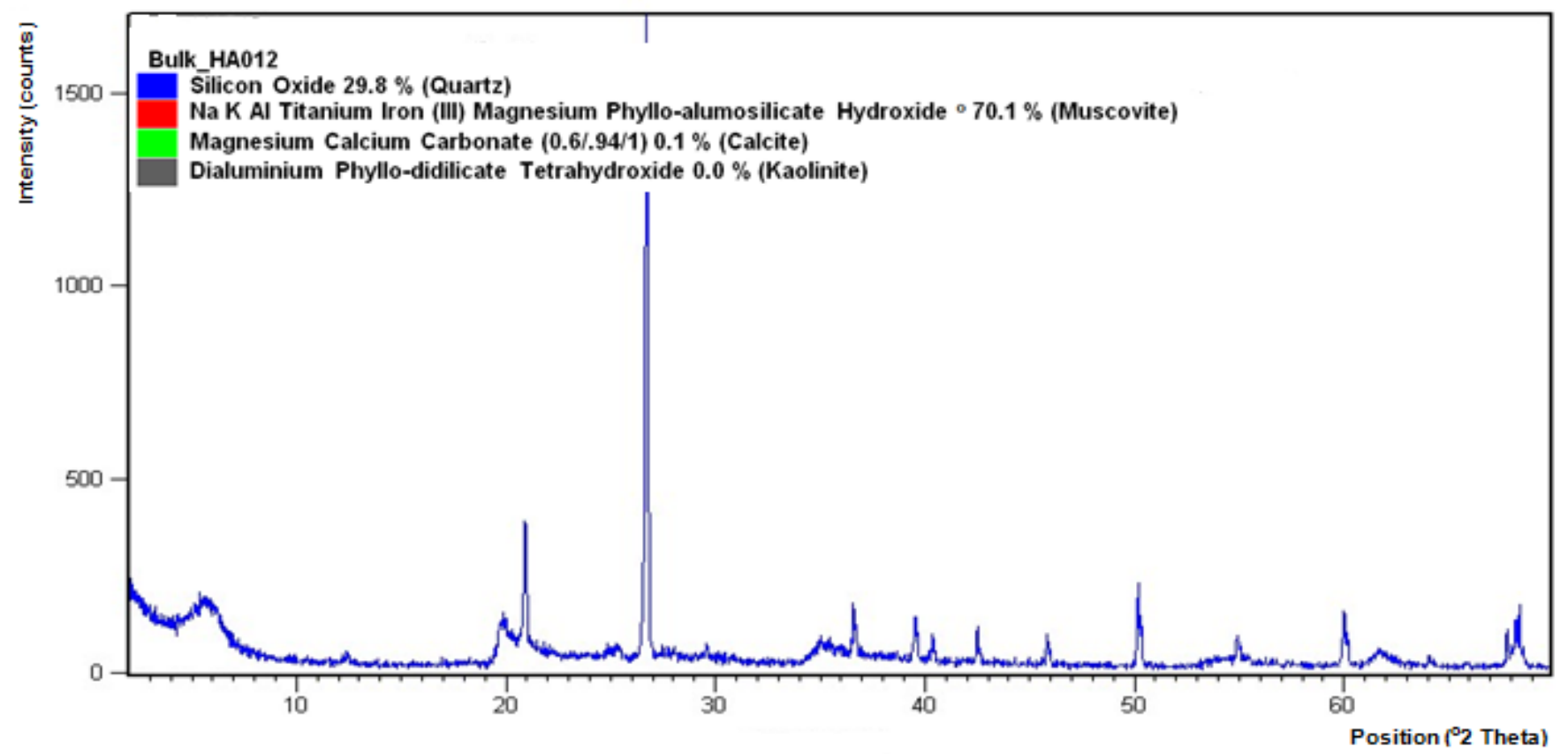

Fig.13 The XRD pattern of clay minerals of the soil sample from Fayo $2(56-91 \mathrm{~cm})$.

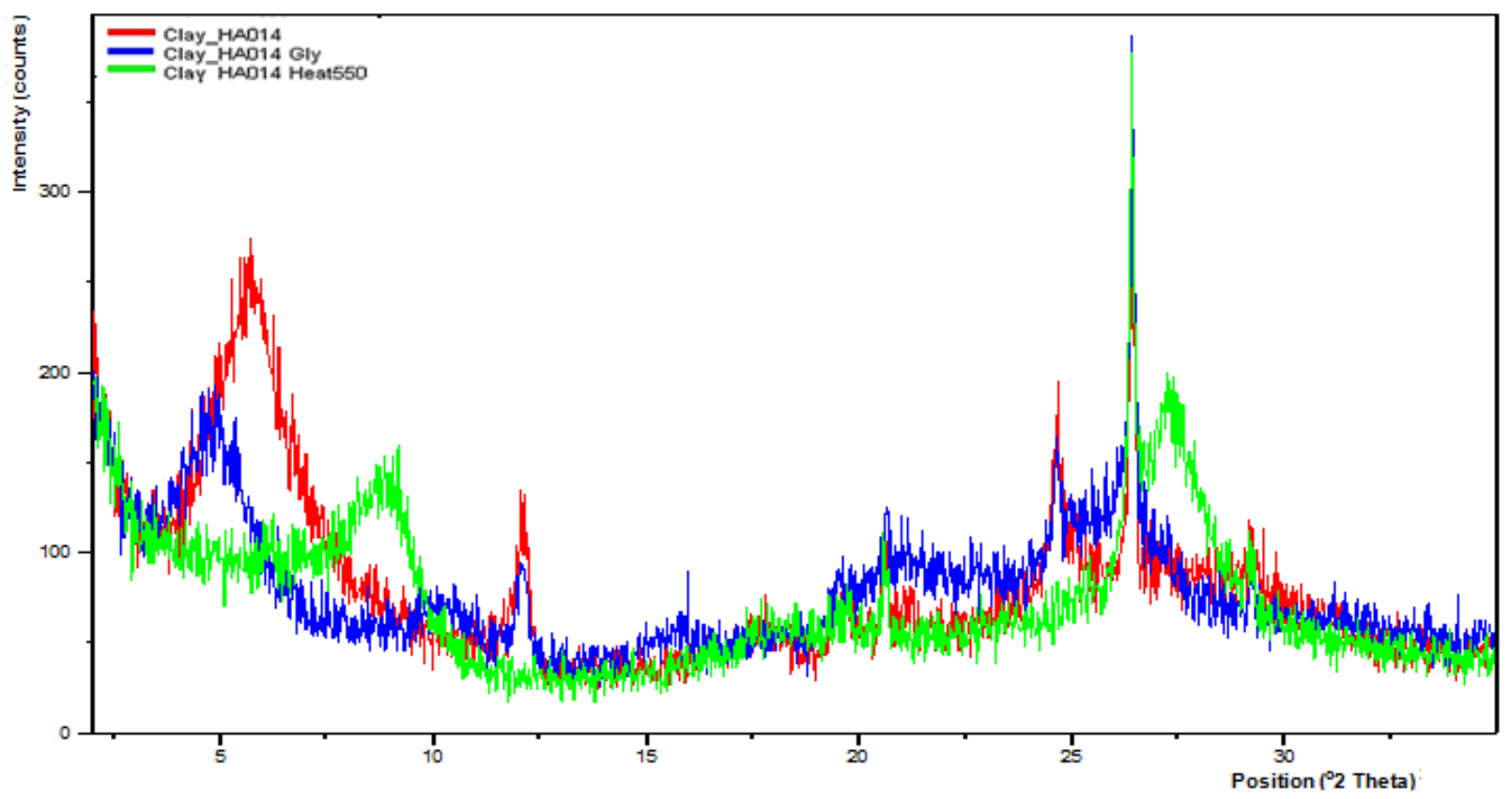


Fig.14 The X RD pattern of bulk minerals of the soil sample from Fayo $2(56-91 \mathrm{~cm})$.

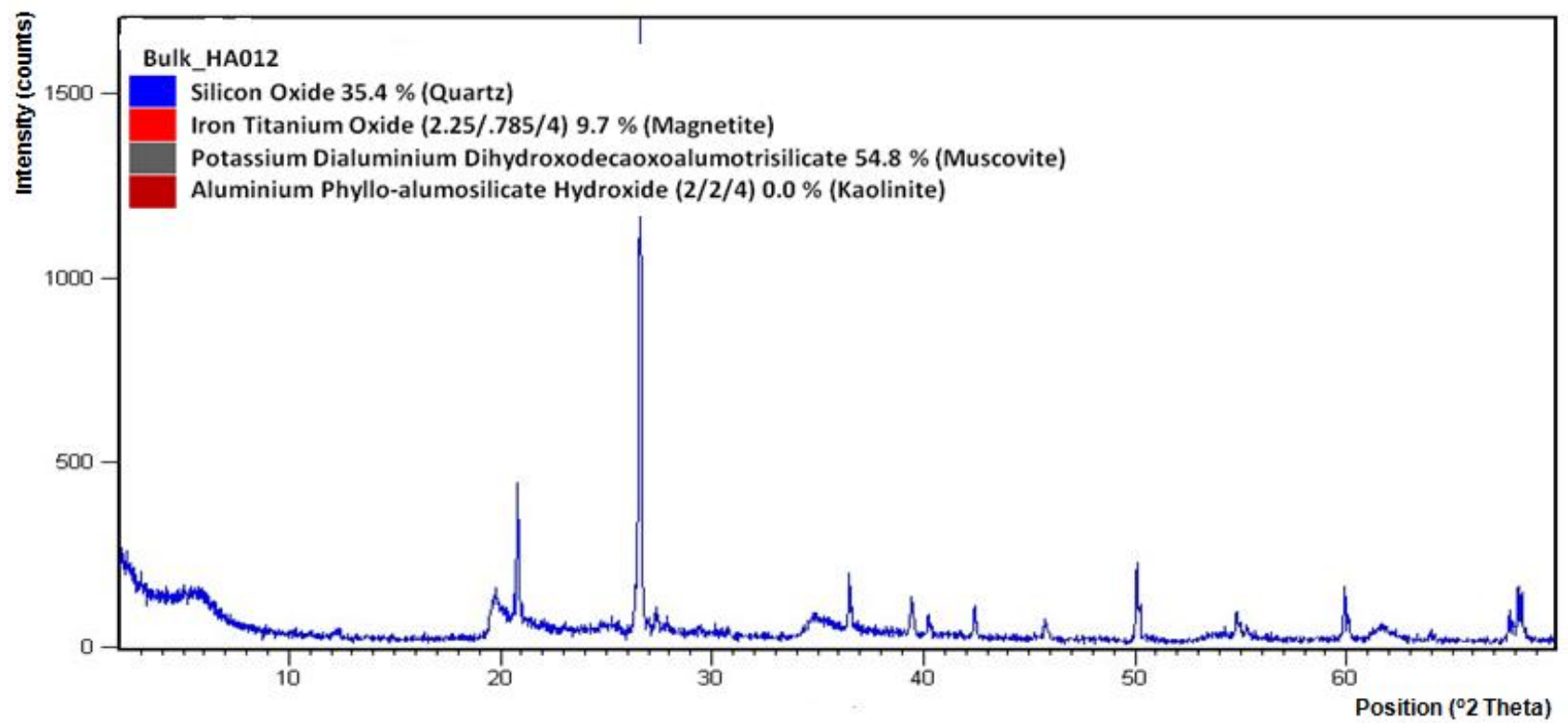

Fig.15 the XRD pattern of clay minerals of the soil sample from Fayo $3(59-97 \mathrm{~cm})$

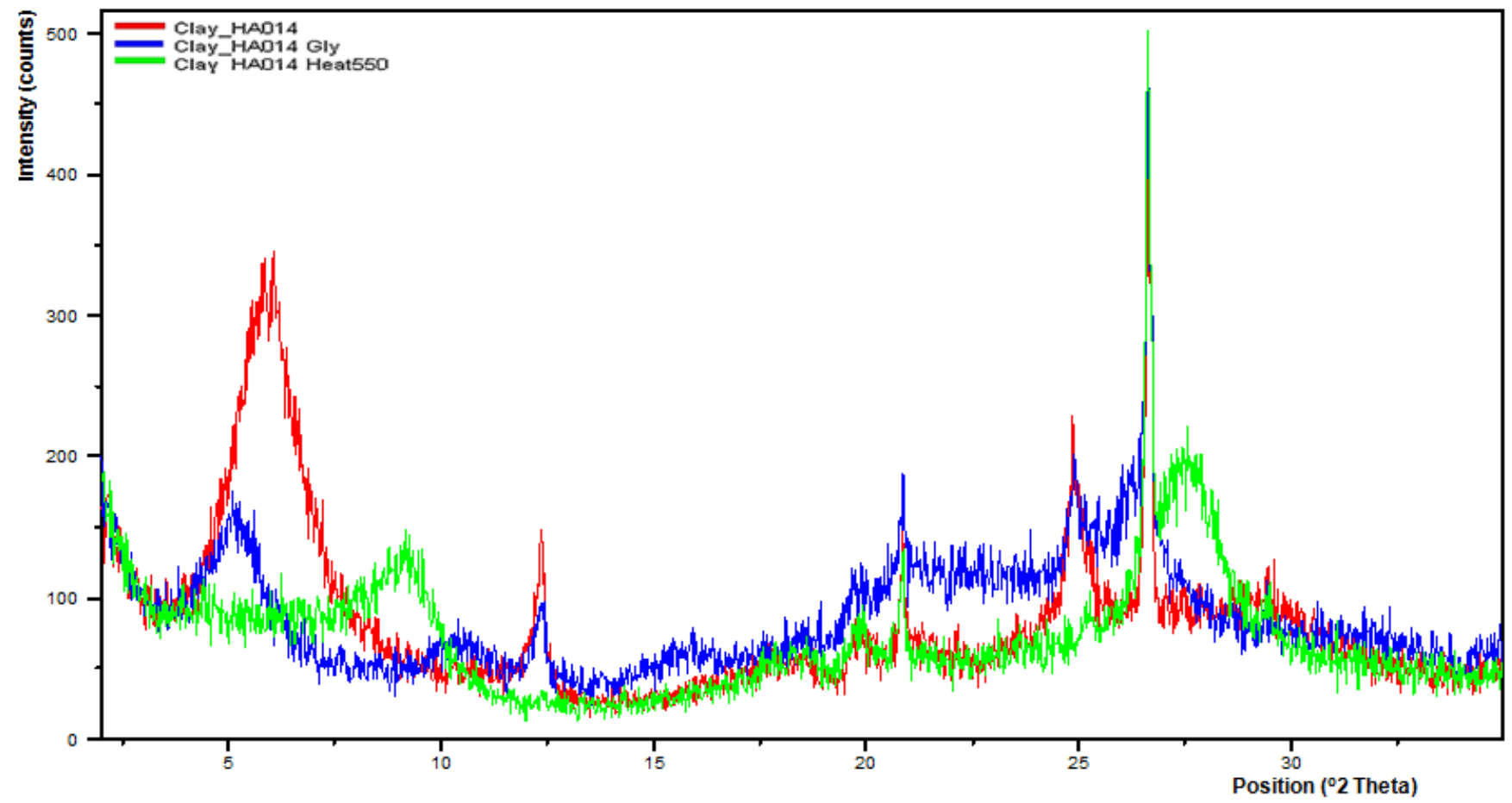


Fig.16 The XRD pattern of bulk minerals of the soil sample from Fayo $3(59-97 \mathrm{~cm})$.

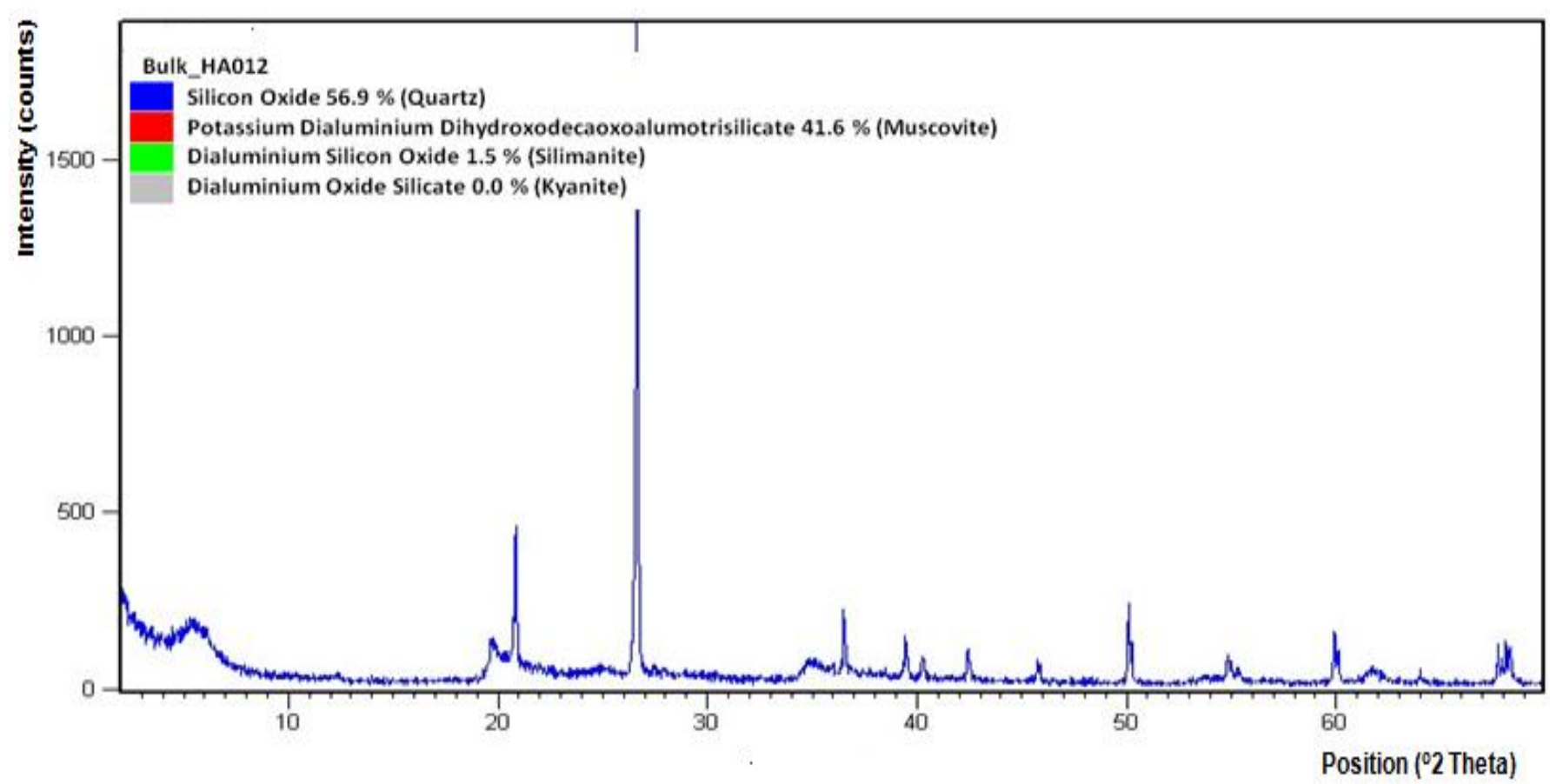

Fig.17 The XRD pattern of clay minerals of the soil sample from Dalami $(60-90 \mathrm{~cm})$.

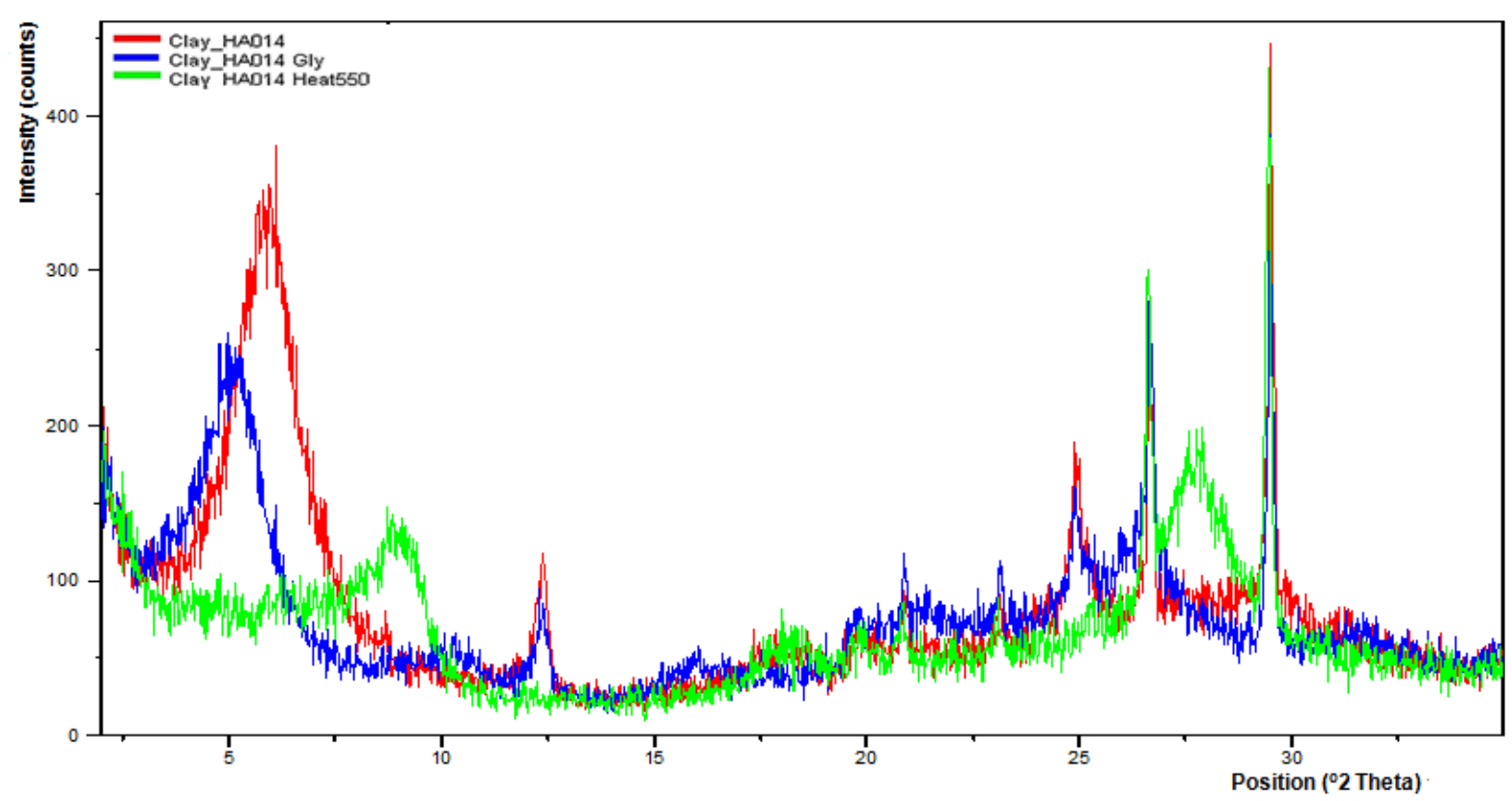


Fig.18 The XRD pattern of bulk minerals of the soil sample from Dalami $(60-90 \mathrm{~cm})$.

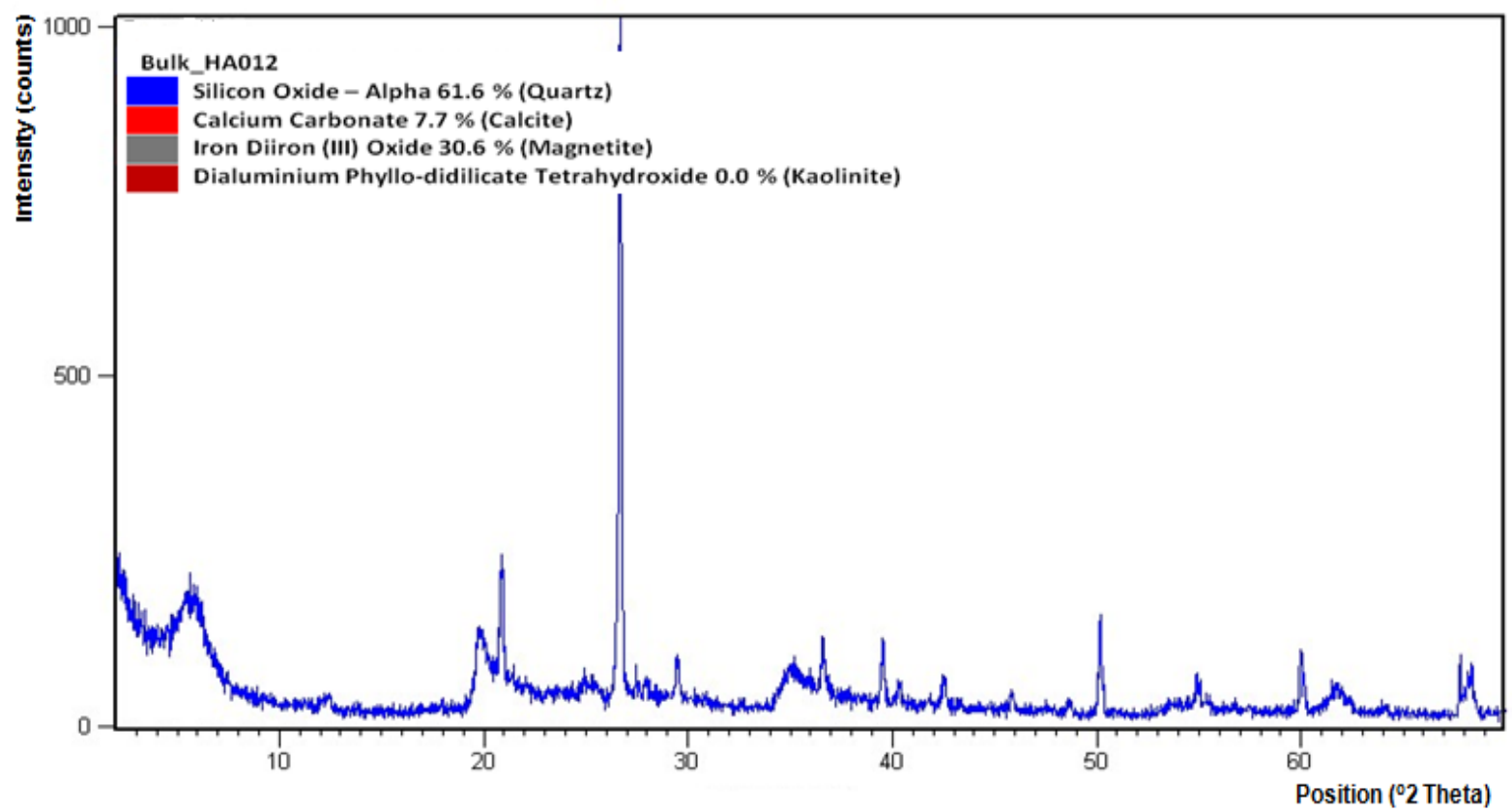

In conclusion, this research study has been conducted on cracking clays soils (Vertisol) in Nuba Mountains in South Kordofan State to characterize and investigated their mineralogical properties. Eight location sites were selected for this study; these sites were along a topographical sequence at the upper clay plains (Habila area) to compare (in toposequence) the type of clay minerals in these plains. The results indicated that the Smectite was found to be the dominant clay minerals.

Generally, it ranges between (84.6, - 49.5 $\%$ ), followed by the kaolinite, the clay mineral kaolinite was recorded in all of the investigated samples with variable percentages ranging between $(8.2 \%-46.45$ $\%)$. Therefore, the presence of Kaolinite indicates accumulation of weathering product. Investigated soils also contain low amount chloride, illite and Smectitel Chlorite. The sequential weathering of the variable rock formation has led to the formation of the intermountain clay plains of the Nuba Mountains of the south Kordofan state. It is anticipated that weathering in the western high lands of Habila area occurred at variable intensities resulted in heterogeneous weathering product indicating that weathering of weatherable mineral was insufficient to the extent that remains of interlaying components have intervene and eventually interlayer the expandable layer silicates rendering it to take the characteristic of two minerals e.g. Montmorillonite and chloride.

The clay fraction of the bulk samples does not provide indication of smectitic clay minerals, the Habila areas contains only clay minerals illite, sillimanite and kaolinite. The quartz and magnetite are everywhere ubiquitous; this distributions pattern would indicate that Pedogenesis weathering of detrital minerals grains was rather extensive due to the action of excessive moisture regimes. In aggregates this mineralogical assemblages occurring in Habila suggest origins of parent materials derived from 
basic igneous Imetamorphic rocks that have under gone weathering and in situ formation of clay minerals that have imposed magnitude of variations in the Pedological features (Caillaud et al., 2004).

\section{References}

Ahmed, N. 1996. Occurrence and distribution of Vertisols. In Ahmad, N., A. Mermut. (ed.). Vertisols and technologies for their management p.1-41. In Soil Science 24, Elsevier, Amsterdam, the Netherlands.

Balwant, S. and H. Susan. 2002. Layer charge characteristics of Smectite from Vertisol of New South Wales. Australian J. Soil Res., 40(7): 1159 - 1170.

Caillaud, J.D.D. Proust, Rishi, F. Martin. 2004. Fe-Rich Clays In A Weathering Profile Developed From Serpentinite Clay And Clay Minerals; 52; no. 6; p. 779-791.

Chizhikova, N.P. 2005. Vertisols of Cuba: Mineralogical Composition and Response to Agrogenic Impacts (Plowing, Irrigation, and Fertilization) Eurasian Soil Sci., Vol. 38, No.10, pp. 1048-1057.

Dudal, R., H. Eswaran. 1988. Distribution Properties and Classification of the Vertisols In: Wilding L.P, Puentes R, editors. Vertisols: their distribution, properties, classification and management. College Station, Texas: Texas A \& M University Printing Center.

Grim, R.E. 1968. Clay mineralogy $2^{\text {nd }}$ ed. New York, M c: G raw-Hill, p.p. 596.

Kladivko E.J. 2001. Tillage Systems and Soil Ecology, Soil Tillage Res., 61, 61-76.

Mc Garry, D. 1996. The Structure and Grain Size Distribution of Vertisols, In: Vertisols and Technologies for Their Management (Eds.: N. Ahmad and A.
Mermut). Developments on Soil Science. Vol. 24. Elsevier, Amsterdam, pp. 231259.

Moore, D.M, R.C. Jr Reynolds. 1989. X-ray Diffraction and the Identification and Analysis of Clay Minerals. Oxford, Oxford University Press, 332 pp.

Osman, R.A. 2006. Mineralogical Characterization of Some Soil Samples From East of Khartoum North (Sudan). Thesis Submitted In Partial Fulfilled Of the Requirement for the Degree of Master Science, Faculty of Agricultural Sciences University of Gazira

Pacheco and Dawoud, H.A. 1976. Exploratory, Soil Survey of North and South Kordofan Ministry of Agriculture Fisheries and Forestry. Soil Survey Administration Wad Medani, Sudan.

Showgi, Omima O.A. 2011. A study on properties and genesis of cracking clay soils in Southern Kordofan, Sudan. Ph.D. Thesis (soil Science), Soil and Water Science Dept., College of Agricultural Studies. Sudan University of Science and Technology. Khartoum.

Thorez, J. 1972. Practical Identification of Clay Minerals, First Edition G. Lelotte Dison Belgium.

Thorez, J. 1975. Phyllosilicates and Clay Minerals A Laboratory Handbook for Their X-Ray Diffraction Analysis Dison, Editions G. Lelotte, pp. 579

Tucker, M. (ed) 1988. Techniques in Sedimentology. Blackweel Scientific Publications California, U .S .A.

Vail, J.R., D.C. Rex. 1971. Tectonic and Geochronological Studies in Sudan. $14^{\text {th }}$ annual Republic. Inst Afr. Geol. Univ Leeds, 44 - 47.

\section{How to cite this article:}

Omima Omer A. Showgi, El-Abbas Doka M. Ali, Hashim Ali Dawoud and Mahgoub Suliman Mohamedain. 2016. Mineralogical Properties of Cracking Clay Soils along Toposequence at Northern Upper Clay Plains of Nuba Mountains South Kordofan, Sudan. Int.J.Curr.Microbiol.App.Sci. 5(8): 745-759.

doi: http://dx.doi.org/10.20546/ijcmas.2016.508.084 